fore render a lymphocyte resistant or sus ceptible to a particular HIV-1 variant. According to our results, changes in the number of $\mathrm{CXCR}^{+}$and $\mathrm{CCR} 5^{+} \mathrm{CD} 4$ cells alter the number of targets for R5 and X4 HIV variants. We agree that HIV-induced modulation of cytokine production in vivo $^{4}$ is more complex than that seen in ex vivo tissues ${ }^{5,6}$. However, the predominance of $\mathrm{CXCR}^{+} \mathrm{CD}^{+} \mathrm{T}$ cells was observed both in fresh blood ${ }^{3}$ and in lymphoid tissues in vivo $^{2}$. Moreover, the relative number of HIV-infected $\mathrm{CD}^{+}{ }^{+} \mathrm{T}$ cells in our ex vivo model is similar to that reported for tissues in vivo ${ }^{5,6}$. Notwithstanding the complexity of in vivo mechanisms of modulation of CCR5 and CXCR4 expression, our results showed that R5 and X4 HIV-1-deplete $\mathrm{CD} 4^{+} \mathrm{T}$ cells in human lymphoid tissue in accordance with the expression pattern of the co-receptors they use.

LEONID MARGolis \& JEAN-ChARLES GRIVEL
Laboratory of Cellular and M olecular Biophysics $\mathrm{N}$ ational institute of $\mathrm{Child}$ Health and Human Development

National Institutes of Health

Bethesda M aryland 20892 USA

email: margolis@helix.nih.gov

1. Grivel, J.-C. \& Margolis, L. CCR5- and CXCR4-tropic HIV-1 are equally cytopathic for their T-cell targets in human lymphoid tissue. Nature Med. 5, 344-346 (1999).

2. Andersson, J. et al. Early reduction of immune activation in lymphoid tissue following highly active HIV therapy. AIDS 12, F123-F129 (1998).

3. Bleul, C.C., Wu, L, Hoxie, J.A., Springer, T.A. \& Mackay, C.R. The HIV coreceptors CXCR4 and CCR5 are differentially expressed and regulated on human T lymphocytes. Proc. Natl. Acad. Sci. USA 94, 1925-1930 (1997)

4. Shearer, G.M. \& Clerici, M. Cytokine profiles in HIV type 1 disease and protection. AIDS Res. Hum. Retroviruses 14 Suppl 2, S149-S152 (1998).

5. Glushakova, S. et al. Evidence for the HIV-1 phenotype switch as a causal factor in acquired immunodeficiency. Nature M ed. 4, 346-349 (1998).

6. Margolis, L.B., Glushakova, S., Grivel, J.C. \& Murphy, P.M. Blockade of CC chemokine receptor 5 (CCR5)tropic human immunodeficiency virus-1 replication in human lymphoid tissue by CC chemokines. J. Clin. Invest. 101, 1876-1880 (1998).

\title{
Keeping an eye on ICSI
}

To the editor-In the April issue of Nature Medicine, Laura Hewitson and colleagues ${ }^{1}$ describe experiments in rhesus monkeys using theincreasingly popular procedureof intracytoplasmic sperm injection (ICSI). The authorsstate that most genetic defects found in children born after ICSI intervention are a result of the technique itself and not because of the transmission of defects inherited from theoneof theparents. Their work affirmsthat ICSI can no longer beconsidered innocuous and that further animal experimentation is required in an attempt to improve the safety of the procedure.

We have considered the risks involved in ICSI and developed some recommendations ${ }^{2,3}$, including the need to limit the number of teams conducting this work and to monitor their performance; to require that these centers abide by agreed ethical guide lines; and that the medical circumstances for which ICSI is indicated are defined.

In France today, more than twenty centers offer ICSI, which accounts for $38 \%$ of all in vitro fertilization procedures. Our survey ${ }^{4,5}$ of 36 French CCPPRBs (Committeefor theProtection of Human Subjects in Biodmedical Research) the French research ethical committees instituted by the law revealed that they were not approached for approval to conduct ICSI. M oreover, no independent form of evaluation exists at either technical or epidemiological levels_a point emphasi sed in a recent report from theFrench Academy of Medicine ${ }^{6}$.

In the absence of appropriateregulation, the practice of ICSI will be subject to disputes and disagreements, and such conflicts will make society at large mistrustful. Furthermore, the public should not be excluded from a debate on the pros and cons of ICSI-a debate that is essential not only for the couples and children concerned, but also for the vision that we have of man and future generations.

GrÉGoIre Moutel, NADĖGe Leroux \& CHRISTIAN HERVÉ

Laboratoire d'éthique médicale et de santé publique, Faculté de médecine N ecker-Université ParisV 156 Rue de Vaugirard

\section{PARIS Cédex 15, France}

email: herve@necker.fr

1. Hewitson, L. et al. Unique checkpoints during the first cell cycle of fertilization after ICSI in rhesus monkeys. Nature Med. 5, 431-433 (1999).

2. Hervé, C.\& Moutel, G. Abnormalities after intracytoplasmic sperm injection, Lancet 346, 1096-1097 (1995).

3. Liebers, I., Bonduelle, M., Van Assche, E., Devroey, P.\& Van Steirteghem, AC. Sex chromosome abnormalities after intracytoplasmic sperm injection. Lancet 346, 1095-1096 (1995).

4. Huriet's law. L88-1138 (20 December 1988) and L94-630 (25 July 1994). Journal Officiel de la République Française 10747-10749 (26 July 1994).

5. Moutel, G., Leroux, N.\& Hervé, C. Analysis of a survey of 36 French research committees on intracytoplasmic sperm injection. Lancet 351 1121-1123 (1998).

6. David, G. La Medecine Saisie par le Principe de Précaution (Communication del'Académie Nationale Française de Médecine). Bull. Acad. Natl. Med. 182, 1219-1228 (1998). 